\title{
Perbandingan Pengaruh Redaman Gilbert dan Ketebalan Bahan terhadap Perubahan Dinamika Magnetisasi pada Nanodot Pt/MnSb dan CoFeAl
}

\author{
Ivana Helga Iriani, Andreas Setiawan, dan Nur Aji Wibowo* \\ Program Studi Fisika, Fakultas Sains dan Matematika, Universitas Kristen Satya Wacana \\ Jl. Diponegoro 52-60, Salatiga 50711
}

\begin{abstract}
Intisari
Penelitian ini menyajikan perbandingan pengaruh redaman Gilbert dan ketebalan nanodot terhadap dinamika magnetisasi dari Pt/MnSb dan CoFeAl dengan menyelesaikan persamaan Landau-Lifshift Gilbert menggunakan Simulator Mikromagnetik. Parameter magnetik yang digunakan dalam penelitian ini mewakili karakteristik $\mathrm{Pt} / \mathrm{MnSb}$ dan $\mathrm{CoFeAl}$ dengan variasi redaman Gilbert 0,4-0,9. Kedua bahan dimodelkan dalam bentuk balok dengan ukuran permukaan $(50 \times 50) \mathrm{nm}^{2}$ dan dengan variasi ketebalan 5-100 nm. Skema simulasi yang digunakan adalah Reduced Barrier Writing dimana sampel berada pada suhu ruang $298 \mathrm{~K}$ sambil diinduksi dengan medan magnetik eksternal yang besarnya meningkat dari 0 hingga 2 Tesla selama 2,5 ns. Hasil penelitian menunjukkan bahwa Pt/MnSb dan CoFeAl memiliki kestabilan termal yang baik untuk berbagai nilai redaman Gilbert dan variasi ketebalan yang dipakai $(>60 \mathrm{kBT})$. Peningkatan redaman Gilbert memperbesar nilai medan nukleasi kedua bahan. Medan nukleasi meningkat pada ketebalan 5-35 nm namun menurun pada ketebalan 40-100 nm. Penguatan redaman Gilbert menyebabkan perbesaran nilai medan koersif bahan CoFeAl dan penurunan untuk bahan $\mathrm{Pt} / \mathrm{MnSb}$. Sementara itu, mempertebal bahan menyebabkan peningkatan medan koersif pada ketebalan 5-35 nm dan penurunan pada ketebalan 40-100 nm. Laju magnetisasi kedua jenis bahan semakin cepat seiring menguatnya nilai redaman Gilbert dan melambat seiring meningkatnya ketebalan.
\end{abstract}

\begin{abstract}
This study presents a comparison of Gilbert damping and nanodot thickness impact on the magnetization dynamics of $\mathrm{Pt} / \mathrm{MnSb}$ and $\mathrm{CoFeAl}$ by solving the Landau-Lifshift Gilbert equation using Micromagnetic Simulator. The magnetic parameters used in this study represent the characteristics of $\mathrm{Pt} / \mathrm{MnSb}$ and $\mathrm{CoFeAl}$ with the variation of Gilbert damping 0.4-0.9. The materials were modeled as a block with a surface size $50 \times 50 \mathrm{~nm}^{2}$ and $5-100 \mathrm{~nm}$ of thickness variation. The simulation scheme used was Reduced Barrier Writing in which the sample was conditioned at room temperature of $298 \mathrm{~K}$ while induced with an external magnetic field which increased from 0 to 2 Tesla for $2.5 \mathrm{~ns}$. The results showed that both, $\mathrm{Pt} / \mathrm{MnSb}$ and $\mathrm{CoFeAl}$, have good thermal stability for chosen Gilbert damping values and thickness variations $(>60 \mathrm{kBT})$. The increase of Gilbert damping magnifies the nucleation field of both materials. The nucleation field increases at 5-35 nm of thickness, however, decreases at 40-100 nm. The strengthening of Gilbert damping magnifies the coercive field values of CoFeAl and reduces for Pt/MnSb. Meanwhile, thicken the materials causes an increase of the coercive field at 5-35 nm of thickness and decreases at 40-100 $\mathrm{nm}$. The magnetization rate of both materials getting faster by the strengthened of Gilbert damping value and slower by thickness increment.
\end{abstract}

Keywords: Gilbert damping; magnetization; thickness.

*Corresponding author: nurajiwibowo@gmail.com

http://dx.doi.org/10.12962/j24604682.v16i3.5460

2460-4682 (CDepartemen Fisika, FSAD-ITS

\section{PENDAHULUAN}

Peningkatan kebutuhan ukuran data penyimpan terjadi terus menerus setiap harinya. Hal ini dikarenakan begitu cepatnya perkembangan teknologi di era ini. Sebagian besar bahkan hampir seluruh manusia di bumi ini menggunakan internet, sosial media, dan berbagai multimedia lain yang menyebabkan aliran data dalam jumlah yang besar [1]. Peneli- tian yang dilakukan dalam beberapa tahun terakhir menunjukkan pertumbuhan eksplosif dari data digital mengalami peningkatan mulai dari $281 \times 10^{18}(281$ Exa) Byte di tahun 2007 (sekitar 45 GB per orang) menjadi $1,8 \times 10^{21}(1,8$ Zetta) Byte di tahun 2011 [2].

Keadaan tersebut menyebabkan banyaknya permintaan atas peningkatan kapasitas penyimpanan data. Sejauh ini, HardDisk Drive (HDD) merupakan salah satu teknologi penyimpanan data berbasis magnetik dengan kerapatan tinggi 


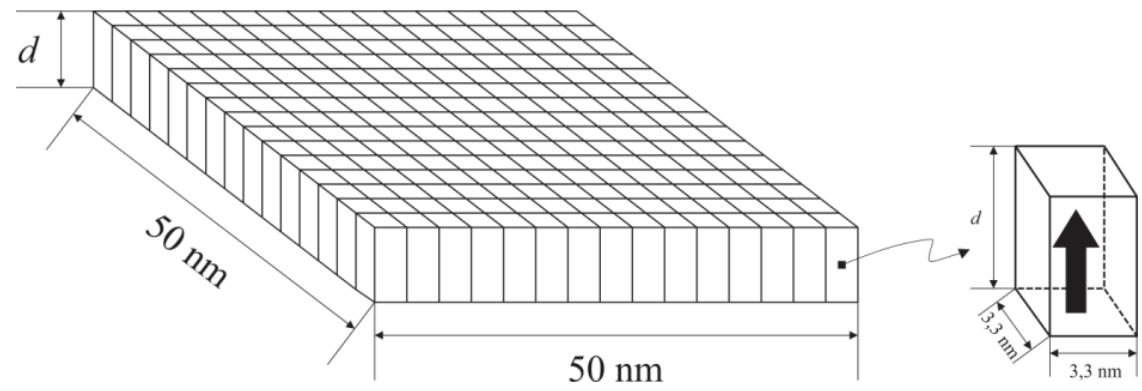

(a)

(b)

Gambar 1: (a) Pemodelan nanodot, (b) Pemodelan satuan sel.

yang mampu memenuhi kebutuhan tersebut. Beberapa opsi teknologi masa depan untuk pembuatan HDD telah diusulkan bahkan penelitian telah dilakukan dalam beberapa tahun terakhir untuk mendapatkan hasil yang lebih baik bagi sistem kerja HDD. HDD dengan perekaman magnetik tegak lurus telah banyak digunakan dan dikembangkan untuk meningkatkan kapasitas penyimpanan dengan mengurangi ukuran partikel magnetik [26].

HDD dengan kapasitas tinggi dapat diperoleh dengan memperkecil ukuran unit sel hingga orde nano-meter [7]. Tentu ukurannya tidak dapat diperkecil secara berlebihan karena akan mengganggu stabilitas termal [3] serta energi magnetik bahan yang dapat menyebabkan hilangnya data [8].

Kestabilan termal minimal yang harus dimiliki bahan untuk menyimpan data hingga 10 tahun dalam suhu ruang adalah 60 kBT [911]. Material yang mampu dibentuk dengan ukuran kecil dan memiliki kestabilan termal $\geq 60 \mathrm{kBT}$ adalah material ferromagnetik beranisotropi tegak lurus atau yang sering disebut Perpendicular Magnetic Anisotropy Materials (PMAM) $[8,10,11]$, contohnya adalah $\mathrm{Pt} / \mathrm{MnSb}$ dan $\mathrm{CoFeAl}$. Pt/MnSb memiliki anisotropi magnetik dan polarisasi spin yang tinggi $[12,13]$. Begitu pula dengan bahan $\mathrm{CoFeAl}$ yang memiliki anisotropi magnetik dan polarisasi spin yang tinggi $[14,15]$. Stabilitas termal PMAM akan tetap bertahan sekalipun dibentuk dalam ukuran nano-meter [8]. Namun demikian, besarnya anisotropi magnetik yang dimiliki oleh PMAM menyebabkan proses baca-tulis data membutuhkan konsumsi medan magnetik yang besar dikarenakan pembalikan arah magnetisasi sulit untuk dikendalikan [16].

Redaman Gilbert dan ketebalan bahan memainkan peranan penting dalam dinamika magnetisasi PMAM [17-20]. Redaman Gilbert mengacu pada relaksasi momen magnetik dalam nanodot. Semakin tinggi redaman Gilbert, momen magnetik akan lebih mudah berbalik arah [21]. Selain itu, redaman Gilbert mempengaruhi energi tanggul, medan pembalik, medan koersif serta laju magnetisasi [22-24]. Geometri bahan feromagnetik secara signifikan juga mempengaruhi kinerja perangkat berbasis magnet [25]. Salah satu aspek geometri yang penting adalah ketebalan [26]. Seperti yang diketahui dalam penelitian sebelumnya bahwa ketebalan berperan penting dalam pembalikan magnetisasi berkaitan dengan baca-tulis data [19]. Oleh karena itu, penelitian ini bertu- juan untuk membandingkan pengaruh dari faktor redaman Gilbert dan ketebalan bahan terhadap dinamika magnetisasi dari $\mathrm{Pt} / \mathrm{MnSb}$ dan $\mathrm{CoFe} \mathrm{Al}$ dengan menggunakan metode simulasi mikromagnetik.

\section{METODOLOGI}

Metode yang digunakan dalam penelitian ini adalah eksperimen komputasi menggunakan perangkat lunak Simulator Mikromagnetik karya H. Takamatsu, K. Sakai, dan S. Konishi dari Universitas Kyushu, Jepang [12]. Simulasi mikromagnetik merupakan metode eksperimen visual berbasis persamaan diferensial terhadap waktu dari magnetisasi bahan feromagnetik yang dikenal sebagai persamaan Landau-Lifshift Gilbert (Pers.(1)) [8].

$$
\begin{aligned}
\frac{d \mathbf{M}^{i}}{d t}= & -\frac{\gamma}{1+\alpha^{2}}\left(\mathbf{M}^{i} \times \mathbf{H}_{e f f}\right) \\
& -\frac{\gamma}{1+\alpha^{2}} \frac{\alpha}{\mathbf{M}_{S}} \times\left(\mathbf{M}^{i} \times \mathbf{H}_{e f f}\right)
\end{aligned}
$$

dengan

$$
\mathbf{H}_{e f f}=\mathbf{H}_{k}+\mathbf{H}_{d}+\mathbf{H}_{e x}+\mathbf{H}_{e x t}+\mathbf{H}_{t h}
$$

Suku pertama pada Pers.(1) menunjukkan bentuk gerak giromagnetik dan suku kedua menunjukkan bentuk redaman Gilbert menyebabkan magnetisasi bahan memiliki kecenderungan untuk mensejajarkan diri dengan medan penginduksi. Pada Pers.(1), $\mathbf{M}^{i}$ adalah magnetisasi dari setiap unit sel, dt adalah waktu integrasi setiap step yaitu sebesar $0,25 \mathrm{ps}$, $\gamma$ adalah rasio giromagnetik $\left(1,76 \times 10^{7} \mathrm{Oe}^{-1} . \mathrm{s}^{-1}\right), \mathbf{H}_{\text {eff }}$ adalah medan magnet efektif, $\alpha$ adalah konstanta redaman Gilbert, dan $\mathbf{M}_{S}$ adalah magnetik saturasi [21].

Pers.(2) mendeskripsikan bahwa medan magnet efektif $\left(\mathbf{H}_{e f f}\right)$ yang berinteraksi dengan magnetisasi bahan merupakan resultan dari beberapa faktor diantaranya adalah medan anisotropi $\left(\mathbf{H}_{k}\right)$, medan demagnetisasi $\left(\mathbf{H}_{d}\right)$, medan pertukaran $\left(\mathbf{H}_{e x}\right)$, medan magnetik eksternal $\left(\mathbf{H}_{e x t}\right)$, dan medan panas $\left(\mathbf{H}_{t h}\right)[19,20,27]$.

Material PMAM yang diteliti adalah $\mathrm{Pt} / \mathrm{MnSb}$ dan $\mathrm{CoFeAl}$ dengan menggunakan konstanta redaman Gilbert dan konstanta giromagnetik secara berturut-turut sebesar 0,4-0,9 dan 
TABEL I: Spesifikasi intrinsik magnetik sampel pada suhu ruang.

\begin{tabular}{lcc}
\hline \hline Sifat Instrinsik Magnetik & Pt/MnSb [12] & CoFeAl [14] \\
\hline & & \\
Magnetik Saturasi (Gauss) & 2100 & 10000 \\
Konstanta Anisotropi (erg/cc) & $3,0 \times 10^{5}$ & $2,3 \times 10^{6}$ \\
Medan Pertukaran (erg/cm) & $1 \times 10^{-7}$ & $3,5 \times 10^{-7}$ \\
\hline \hline
\end{tabular}

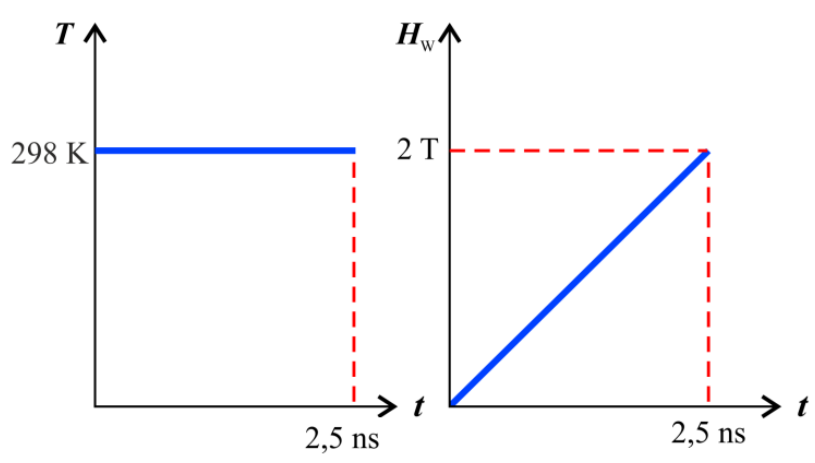

Gambar 2: Skema simulasi Reduced Barrier Writing (RBW).

$1,76 \times 10^{7} \mathrm{Oe}^{-1} \mathrm{~s}^{-1}$. Material tersebut memiliki sifat intrinsik magnetik seperti yang tertera pada Tabel I.

Bahan-bahan tersebut dimodelkan dalam nanodot berbentuk balok dengan ukuran permukaan $(50 \times 50) \mathrm{nm}^{2}$ dan variasi ketebalan 5-100 nm. Nanodot tersusun dari $15 \times 15$ unit sel dengan ukuran permukaan untuk setiap sel $(3,3 \times 3,3)$ $\mathrm{nm}^{2}$. Model sampel divisualisasikan pada Gambar 1 .

Skema simulasi yang digunakan dalam penelitian ini adalah Reduced Barrier Writing (RBW) yang dijalankan dengan sampel berada dalam suhu ruang $298 \mathrm{~K}$ secara konstan (Gambar 2(a)). Mula-mula sampel berada dalam kondisi magnetisasi tersaturasi pada arah x-positif. Kemudian diberikan medan magnetik eksternal ke arah sumbu x-negatif yang besarnya meningkat secara linear dari 0 Tesla hingga 2 Tesla selama 2,5 ns. Skema simulasi ditunjukkan pada Gambar 2.

Pada simulasi ini, sampel diasumsikan berada pada sistem terisolasi dimana medan pertukaran dan medan demagnetisasi muncul sebagai hasil interaksi antara unit-unit sel. Kurva standar untuk mekanisme pembalikan magnetisasi pada suhu ruang ditunjukkan pada Gambar 3.

Pada keadaan awal, bahan tersaturasi pada $\mathbf{M}_{2}$. Medan induksi yang diperlukan untuk mengawali perubahan magnetisasi disebut medan nukleasi $\left(\mathbf{H}_{n}\right)$, sedangkan medan yang diperlukan untuk membalikkan 50\% magnetisasi $(\mathbf{M}=0)$ disebut medan koersif $\left(\mathbf{H}_{c}\right)$ [29]. Ketika medan nukleasi telah tercapai, magnetisasi material mulai bergerak menuju $\mathbf{M}_{1}$ dan menyearahkan diri dengan medan penginduksi $(\mathbf{H})$ $[24,28,29]$. Gerakan ini terjadi dalam waktu tertentu $(\Delta \mathrm{t})$ dengan perubahan magnetisasi material sebesar $\Delta M$. Dalam mekanisme ini, laju magnetisasi dinyatakan sebagai hasil dari $\frac{\Delta M}{\Delta t}[31]$.

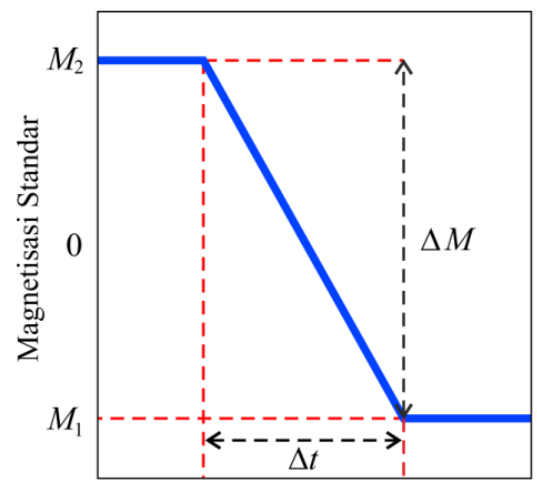

Waktu, $t$

(a)

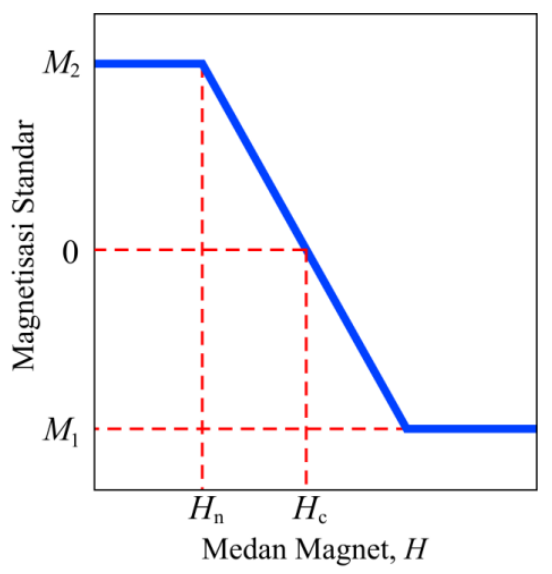

(b)

Gambar 3: Kurva pembalikan magnetisasi standar sehubungan dengan, (a) peningkatan medan magnetik eksternal, (b) peningkatan waktu.

\section{HASIL DAN PEMBAHASAN}

Pada keadaan awal, $\mathrm{Pt} / \mathrm{MnSb}$ maupun CoFeAl memiliki level energi dasar, atau dapat juga disebut berada pada keadaan energi minimum dimana keadaan ini menunjukkan bahwa bahan tersebut dalam keadaan setimbang. Selanjutnya energi bahan akan meningkat secara drastis hingga mencapai level energi maksimum. Hal ini menunjukkan keadaan ketika polarisasi magnetik bahan tepat akan membalik. Kemudian energi bahan akan turun kembali ke level energi minimum. Selisih antara energi minimum dan maksimum disebut sebagai energi tanggul $(\Delta \mathrm{E})$. Energi tanggul ini memberikan informasi mengenai kestabilan termal dari suatu bahan. Ketika nilai energi tanggul kecil, maka stabilitas termalnya pun menjadi kurang baik dan media perekaman tersebut menjadi kurang stabil dalam menyimpan data dalam jangka panjang. Hal ini dapat menyebabkan hilangnya data. Sedangkan semakin besar energi tanggul dari suatu bahan, maka stabilitas termalnya juga semakin baik dan baik pula dalam menyimpan data untuk jangka panjang [10]. Stabilitas termal bahan merupakan syarat dasar apakah suatu bahan memiliki potensi untuk 


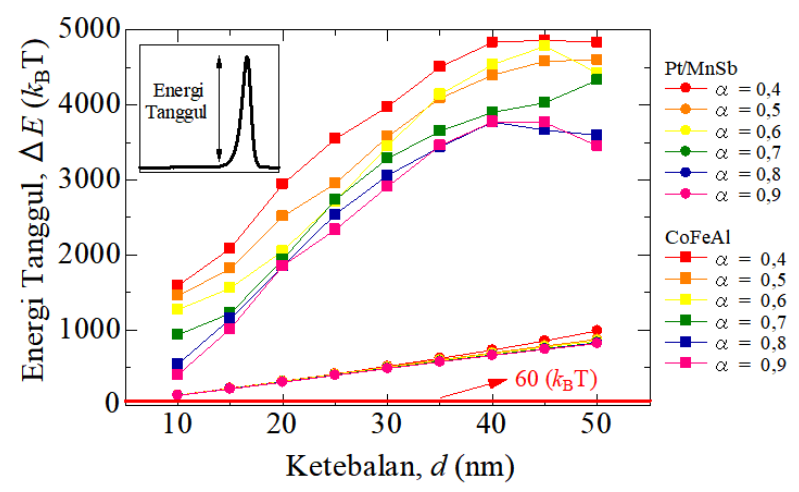

Gambar 4: Besar energi tanggul (E) Pt/MnSb dan CoFeAl untuk berbagai nilai redaman Gilbert dengan variasi ketebalan.

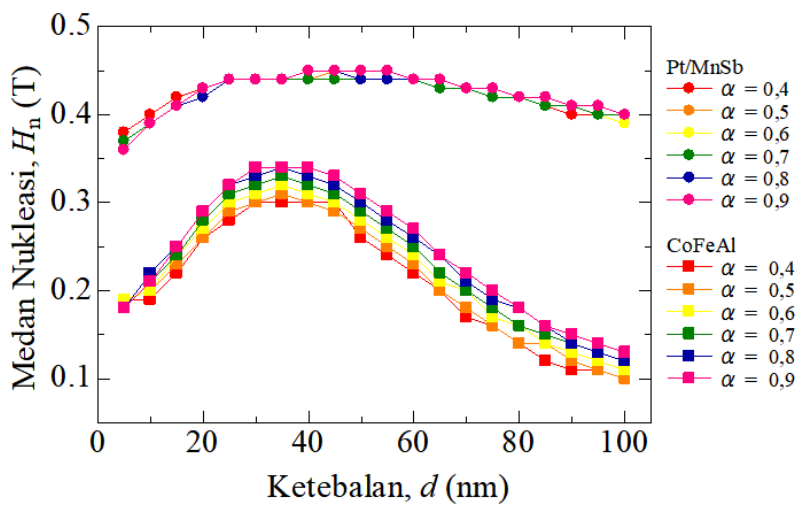

Gambar 5: Medan nukleasi Pt/MnSb dan CoFeAl untuk berbagai nilai redaman Gilbert dengan variasi ketebalan.

dipergunakan sebagai media penyimpanan HDD. Bahan dengan kestabilan termal $\geq 60 \mathrm{kBT}$ dinyatakan memenuhi syarat tersebut.

Hasil perhitungan energi tanggul dari bahan $\mathrm{Pt} / \mathrm{MnSb}$ dan $\mathrm{CoFeAl}$ untuk berbagai nilai redaman dengan variasi ketebalan ditunjukkan dalam Gambar 4. Dari hasil tersebut dapat dilihat bahwa baik $\mathrm{Pt} / \mathrm{MnSb}$ maupun $\mathrm{CoFeAl}$, dalam semua nilai redaman dan variasi ketebalan, memiliki energi tanggul $>60 \mathrm{kBT}$. Hal ini memastikan bahwa bahan tersebut memenuhi syarat sebagai bahan yang mampu menyimpan data dengan stabil pada suhu ruang hingga 10 tahun. Bahan $\mathrm{CoFeAl}$ memiliki energi tanggul yang lebih besar dibandingkan dengan bahan $\mathrm{Pt} / \mathrm{MnSb}$. Perbesaran nilai redaman Gilbert menyebabkan penurunan energi tanggul [24]. Hal ini berlaku untuk kedua bahan. Sedangkan memperbesar ketebalan bahan juga dapat meningkatkan energi tanggulnya [30]. Untuk bahan Pt/MnSb, energi tanggul meningkat secara linier. Sedangkan untuk bahan CoFeAl, energi tanggul meningkat secara tak linier.

Informasi mengenai medan nukleasi $\left(\mathbf{H}_{n}\right)$ untuk berbagai nilai redaman Gilbert dengan variasi ketebalan pada mekanisme pembalikan magnetisasi $\mathrm{Pt} / \mathrm{MnSb}$ dan $\mathrm{CoFeAl}$ disajikan dalam Gambar 5. Medan nukleasi berhubungan

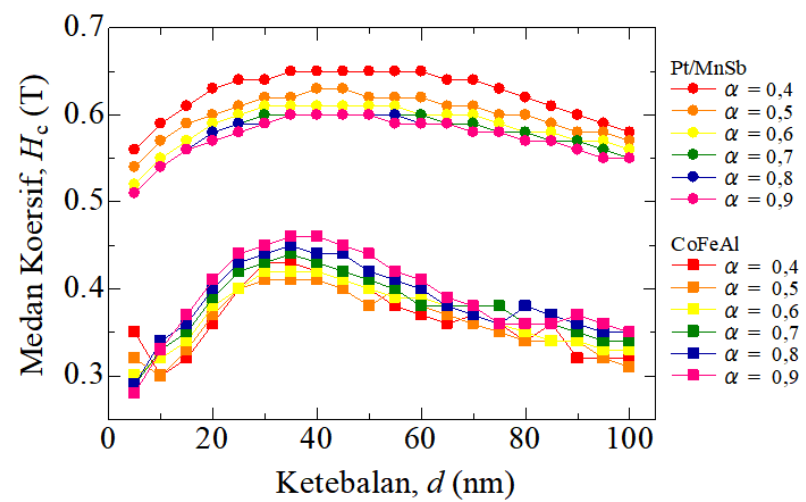

Gambar 6: Medan koersif Pt/MnSb dan CoFeAl untuk berbagai nilai redaman Gilbert dengan variasi ketebalan.

dengan besarnya medan magnet minimum yang dibutuhkan untuk memulai pergerakan magnetisasi bahan [28]. Diperoleh bahwa nilai medan nukleasi dari bahan $\mathrm{Pt} / \mathrm{MnSb}$ lebih besar dibandingkan dengan bahan CoFeAl. Perbesaran nilai redaman Gilbert menyebabkan peningkatan medan nukleasi [31]. Sedangkan untuk bahan $\mathrm{Pt} / \mathrm{MnSb}$, medan ini cenderung memiliki nilai medan nukleasi yang sama untuk masingmasing nilai redaman Gilbert. Nilai medan nukleasinya pun juga memiliki kecenderungan berubah secara tak linier pada ketebalan 5-100 $\mathrm{nm}$.

Informasi mengenai medan koersif $\left(\mathbf{H}_{c}\right)$ untuk berbagai nilai redaman Gilbert dengan variasi ketebalan pada mekanisme pembalikan magnetisasi $\mathrm{Pt} / \mathrm{MnSb}$ dan $\mathrm{CoFeAl}$ disajikan dalam Gambar 6. Medan koersif berhubungan dengan besarnya medan pembalik yang dibutuhkan dalam mekanisme pembalikan magnetisasi [5]. Diperoleh hasil yang sama dengan medan nukleasi bahwa besar medan koersif dari bahan $\mathrm{Pt} / \mathrm{MnSb}$ lebih besar dibandingkan dengan bahan CoFeAl. Pola kurvanya pun serupa dengan medan nukleasi yaitu memiliki kecenderungan meningkat pada ketebalan 5-35 nm dan menurun pada ketebalan $40100 \mathrm{~nm}$ secara kuadratik [30]. Untuk bahan $\mathrm{Pt} / \mathrm{MnSb}$, perbesaran nilai redaman Gilbert menyebabkan penurunan medan koersif $[24,31]$ dan berlaku sebaliknya untuk bahan CoFeAl dimana perbesaran nilai redaman Gilbert menyebabkan peningkatan medan koersif.

Laju magnetisasi $\mathrm{Pt} / \mathrm{MnSb}$ maupun $\mathrm{CoFeAl}$ untuk nilai redaman Gilbert 0,4 dan 0,5 dengan variasi ketebalan disajikan dalam Gambar 7. Terlihat bahwa nilai laju magnetisasi dari Pt/MnSb lebih besar dibandingkan dengan CoFeAl. Perbesaran nilai redaman Gilbert akan meningkatkan laju magnetisasinya [31]. Sedangkan peningkatan ketebalan bahan akan menurunkan laju magnetisasinya [30].

\section{SIMPULAN}

Pengaruh redaman Gilbert dan ketebalan bahan terhadap dinamika magnetisasi material PMAM Pt/MnSb dan $\mathrm{CoFeAl}$ telah dilakukan dengan menyelesaikan persamaan Landau- 


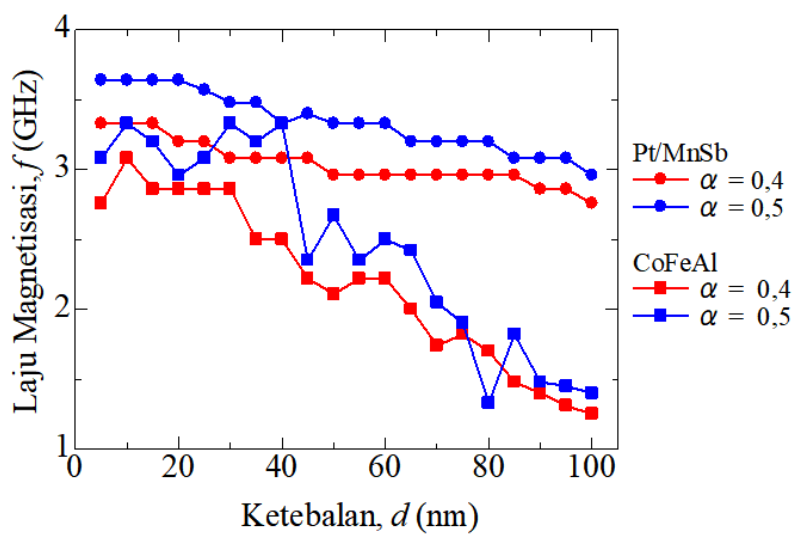

Gambar 7: Laju magnetisasi Pt/MnSb dan CoFeAl untuk nilai redaman Gilbert 0,4 dan 0,5 dengan variasi ketebalan.
Lifshift Gilbert. Diperoleh hasil bahwa $\mathrm{Pt} / \mathrm{MnSb}$ maupun CoFeAl memiliki kestabilan termal yang baik untuk berbagai nilai redaman Gilbert dan variasi ketebalan. Perbesaran redaman Gilbert akan meningkatkan nilai medan nukleasi kedua bahan. Peningkatan medan nukleasi juga terjadi pada ketebalan 5-35 nm namun terjadi penurunan pada ketebalan 40-100 nm. Perbesaran redaman Gilbert menyebabkan peningkatan nilai medan koersif bahan $\mathrm{CoFeAl}$ dan penurunan untuk bahan $\mathrm{Pt} / \mathrm{MnSb}$. Sedangkan perbesaran ketebalan bahan menyebabkan peningkatan medan koersif pada ketebalan 5-35 nm dan penurunan pada ketebalan 40-100 nm. Laju magnetisasi meningkat seiring meningkatnya nilai redaman Gilbert dan menurun seiring meningkatnya ketebalan bahan.
[1] I.A.T. Hashem, I. Yaqoob, N. B. Anuar, S. Mokhtar, A. Gani, and S. Ullah Khan, "The Rise of Big Data on Cloud Computing: Review and Open Research Issues", Information Systems, vol. 47, pp. 98-115, Jan. 2015.

[2] Y. Shiroishi, et al., "Future Options for HDD Storage", IEEE Transactions on Magnetics, vol. 45, no. 10, pp. 3816-3822, Oct. 2009.

[3] R. Wood, "Future Hard Disk Drive Systems", Journal of Magnetism and Magnetic Materials, vol. 321, no. 6, pp. 555-561, Mar. 2009.

[4] "The Evolution of HDDs in the Near Future: Speaking with Seagate CTO, Mark Re", [Online]. Available: https://www.anandtech.com/show/10470/the-evolution-ofhdds-in-the-near-future-speaking-with-seagate-cto-mark-re. [Accessed: 06-Nov-2018].

[5] R. Radhakrishnan, B. Vasi, M. Erden, and C. He, "Characterization of Heat-Assisted Magnetic Recording Channels", DIMACS Series in Discrete Mathematics and Theoretical Computer Science Volume, vol. 73, Jan. 2007.

[6] D. Weller, et al., "High Ku Materials Approach to 100 Gbits/in2", IEEE Transactions on Magnetics, vol. 36, no. 1, pp. 10-15, Jan. 2000.

[7] C. Kim, et al., "'FePt Nanodot Arrays with Perpendicular Easy Axis, Large Coercivity, and Extremely High Density", Applied Physics Letters, vol. 91, no. 17, p. 172508, Oct. 2007.

[8] B. Purnama, M. Koga, Y. Nozaki, and K. Matsuyama, "Stochastic Simulation of Thermally Assisted Magnetization Reversal in Sub-100nm Dots With Perpendicular Anisotropy", Journal of Magnetism and Magnetic Materials, vol. 321, no. 9, pp. 13251330, May 2009.

[9] U.M.N. Azizah and N.A. Wibowo, "Characteristic of Nanobarium-ferrite as Recording Media Using HAMR Technology", Chiang Mai Journal of Science, vol. 44, no. 4, pp. 16691675, Oct. 2017 [URL]: http://it.science. cmu.ac.th/ ejournal/journalDetail.php? journal_id=8492

[10] C. Augustine, et al., "Numerical Analysis of Domain Wall Propagation for Dense Memory Arrays", in 2011 International Electron Devices Meeting, Washington, DC, USA, 2011, pp. 17.6.1-17.6.4

[11] P. Krone, "Magnetization Reversal Processes of Nanostructure Arrays", Sep. 2011. [URL]:https://nbn-resolving.org /urn:nbn:de:bsz:ch1-qucosa-71358

[12] N.A. Wibowo, F.S. Rondonuwu, and B. Purnama, "Low Writing Field on Perpendicular Nano-ferromagnetic", Journal of Magnetics, vol. 19, no. 3, pp. 237-240, Sep. 2014.

[13] I. Galanakis, "Surface Properties of the Half-and Full-Heusler Alloys", Journal of Physics: Condensed Matter, vol. 14, no. 25, pp. 6329-6340, Jul. 2002.

[14] U.M.N. Azizah, S. Trihandaru, and N.A. Wibowo, "Micromagnetic Study of Exchange Interaction Effect on Magnetization Reversal Mode of CoFeAl", AIP Conference Proceedings, vol. 1710, no. 1, p. 030014, Feb. 2016.

[15] M. Belmeguenai, et al., "Magnetic and Structural Properties of Co2FeAl Thin Films Grown on Si Substrate", Journal of Magnetism and Magnetic Materials, vol. 373, pp. 140-143, Jan. 2015.

[16] S. Alebrand, et al., "Light-induced Magnetization Reversal of High-Anisotropy TbCo Alloy Films", Applied Physics Letters, vol. 101, no. 16, p. 162408, Oct. 2012.

[17] M. Oogane, et al., "Magnetic Damping in Ferromagnetic Thin Films", Japanese Journal of Applied Physics, vol. 45, no. 5A, pp. 3889-3891, May 2006.

[18] Y. Zhao, et al., "Experimental Investigation of TemperatureDependent Gilbert Damping in Permalloy Thin Films", Scientific Reports, vol. 6, no. 1, Sep. 2016.

[19] Y. Hou, and K.M. Krishnan, "Thickness-Dependent Magnetization Reversal Behavior of Lithographic IrMn/Fe Ring Structures", Journal of Applied Physics, vol. 111, no. 7, p. 07B905, Mar. 2012.

[20] N.A. Wibowo and C. Handoyo and L.R. Sasongko, "Thermally Activated Magnetic Switching Mode for Various Thicknesses of Perpendicularly Ferromagnetic Nano-dot", Nanoscience \& Nanotechnology-Asia, Volume 9, Issue 2, 31-May-2019.

[21] N.A. Herianto, F.S. Rondonuwu, and N.A. Wibowo, 'Damping Dependence of Reversal Magnetic Field on Co-based NanoFerromagnetic with Thermal Activation", Smart Science, vol. 3, no. 1, pp. 16-20, Jan. 2015.

[22] B. Purnama, I. Ismail, and S. Suharyana, "Kajian Simulasi Mikromagnetik: Ketergantungan Medan Koersif dengan Besaran Intrinsik Nano-Dot Magnetik dengan Anisotropi Tegak Lurus", Jurnal Fisika dan Aplikasinya, vol. 9, no. 1, pp. 30-33, Jan. 2013. 
[23] T. Schrefl, H. Forster, D. Suess, W. Scholz, V. Tsiantos, and J. Fidler, "Micromagnetic Simulation of Switching Events", in Advances in Solid State Physics, B. Kramer, Ed. Berlin, Heidelberg: Springer Berlin Heidelberg, 2001, pp. 623-635.

[24] W. Natalis Handayani, A. Setiawan, and N. Wibowo, "Gilbert Damping Effect on Thermally Assisted Magnetization Reversal of Perpendicular Magnetized Nano-Dot", International Journal of Science and Engineering Investigations, vol. 2, no. 16, pp. 26-31, May 2013. [URL]:http://www.ijsei.com/papers/ijsei21613-06.pdf

[25] B. Purnama, "Karakteristik Magnetik Lapisan Tipis Ni-Fe Sebagai Flat Core Flux Gate Sensor", Jurnal Pendidikan Fisika Indonesia, vol. 9, no.2, hln. 191-196, 2013

[26] Y. Hui, W. Cheng, P. Yan, J. Chen, and X. Miao, 'Thickness Dependence of Magnetic Properties in La-Co Substituted Strontium Hexaferrite Films With Perpendicular Anisotropy", Journal of Magnetism and Magnetic Materials, vol. 390, pp. 56-60, 2015.

[27] T. Schrefl, J. Fidler, D. Suess, W. Scholz, and V. Tsiantos, "Micromagnetic Simulation of Dynamic and Thermal Effects", in Handbook of Advanced Magnetic Materials, Y. Liu, D. J. Sell- myer, and D. Shindo, Eds. Boston, MA: Springer US, 2006, pp. 128-146.

[28] H.J. Richter, and S.D. Harkness, "Media for Magnetic Recording Beyond 100 Gbit/in.2", MRS Bulletin, vol. 31, no. 5, pp. 384-388, May 2006.

[29] R. Belhi, A.A. Adjanoh, J. Vogel, M. Ayadi, and K. Abdelmoula, "Magnetization Reversal Dynamics, Nucleation, Pinning, and Domain Wall Propagation in Perpendicularly Magnetized Ultrathin Cobalt Films: Influence of The Co Deposition Rate", Journal of Applied Physics, vol. 108, no. 9, p. 093924 , Nov. 2010.

[30] P.P. Aji, F.S. Rondonuwu, and N.A. Wibowo, "Thickness Dependence of Magnetic Switching Dynamics of Barium-Ferrite as A High-Density Perpendicular Magnetic Storage Media”, Jurnal Pendidikan Fisika Indonesia, vol. 13, no. 2, pp. 112-118, Jul. 2017.

[31] C.F. Irawan, A. Pamilih, F.S. Meta, and N.A. Wibowo, "Magnetization Switching Dynamics in Barium-Ferrite Nano-Dot: Dependence on Magnetic Damping Constant", Journal of Physics: Conference Series, vol. 1153, p. 012055, Feb. 2019. 